\title{
Carbonatite magmas in the mantle: Evidence and relationship to kimberlites, orangeites and lamproites
}

Harmer, R.E.

Laboratory Division, Council for Geoscience, Private Bag X112, Pretoria 0001

Kimberlites and related diamond-bearing igneous rocks are universally accepted as representing discrete magma types of mantle origin. Carbonatites, however, are commonly regarded as "secondary" magmas produced during the differentiation of silicate parental magmas. Experimental and isotopic data now available indicate that carbonatites form directly from primitive carbonate mantle melts derived from sources with similar evolutionary histories to those producing kimberlites.

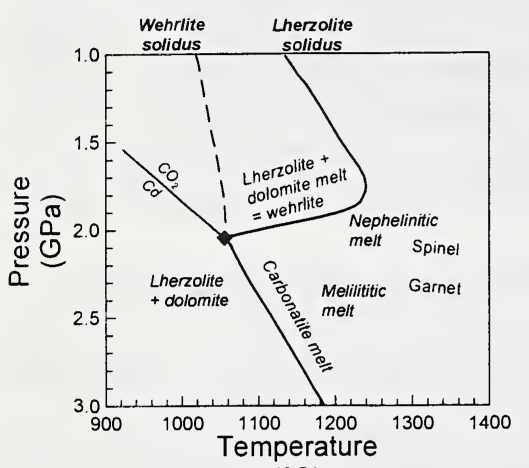

$\left({ }^{\circ} \mathrm{C}\right)$

Figure 1: Sketch of peridotite- $\mathrm{CO}_{2}$ solidus with melt compositions

\section{Experimental data}

A substantial amount of experimental data now exists to show that the near-solidus melts of carbonated peridotite are magnesian carbonate liquids at pressures of 2-3 GPa (Wallace and Green, 1988; Sweeney, 1994). Petrologists have been somewhat reluctant to accept that carbonatites found at surface are indeed derived from such melts. This is largely attributable to: (1) the perception that surface carbonatites are calcitic rather than dolomitic; and (2) the fact that the carbonate melts are formed at the high pressure side of a substantial $\left( \pm 150^{\circ} \mathrm{C}\right)$ thermal maximum (or ledge) in the peridotite- $\mathrm{CO}_{2}$ solidus and should thus be extinguished on ascent (Fig. 1). While calcitic carbonatites are certainly dominant in areas of continental rifting, dolomitic carbonatites are common in the shield areas of Canada and southern Africa. These high mg\# magnesian carbonatites are compositionally similar to the experimental melts suggesting that a mechanism must exist to allow carbonate melts to ascend to surface (Fig. 2).

Ascending across the solidus, carbonate melt disappears through reaction with enstatite in the lherzolite by the reaction dolomite +4 enstatite $\leftrightarrow$ diopside +2 forsterite $+2 \mathrm{CO}_{2}$ which essentially changes the reacted lherzolite to a wehrlite. At pressures below $3 \mathrm{GPa}$ carbonate melt can occur in equilibrium with wehrlite but is more calcic. If ascending melt becomes channelled, then it could be possible for batches of carbonate melt to ascend up conduits sheathed with protective linings of wehrlite. In

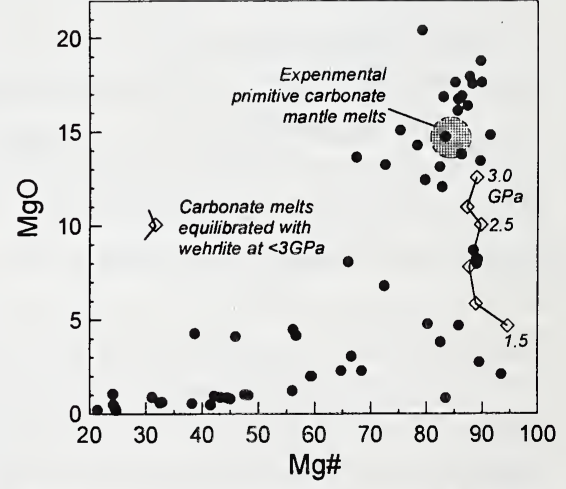

Figure 2: Compositions of southern African carbonatites compared with experimental melts this way both evolved calcic and primitive magnesian carbonate liquids may ascend through the mantle. It is obvious from these relationships that carbonatites would not be able to carry mantle xenoliths: indeed rare mantle fragments are only found in carbonatite diatremes where emplacement from mantle depths is likely to have been rapid. The reaction products of primitive carbonate melts with mantle lherzolite have been recognised in xenolith suites from a number of areas (e.g. Rudnick et al., 1993; Ionov et al., 1993). 


\section{Isotopic data}

Carbonatites are characterised by a remarkably restricted range of $\varepsilon_{\mathrm{Sr}}-\varepsilon_{\mathrm{Nd}}$ values - young ( $\left.<200 \mathrm{Ma}\right)$ carbonatites having less variability in these parameters than oceanic basalts. Despite penetrating continental lithospheres of widely different ages, thicknesses and complexities, carbonatites (excluding southern African complexes) contain no isotopic components not found in oceanic

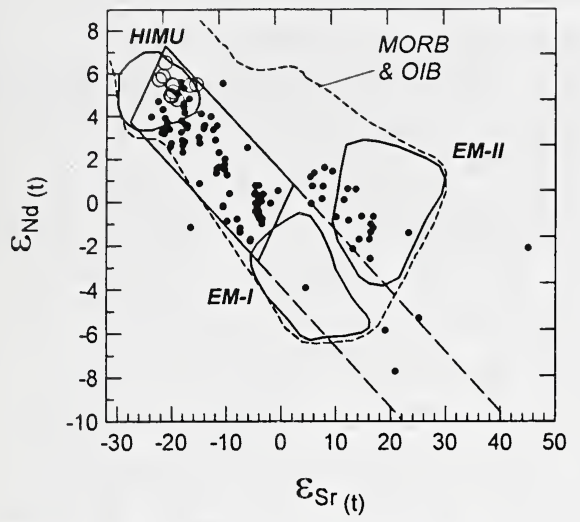

Figure 3: $\varepsilon_{\mathrm{Sr}}-\varepsilon_{\mathrm{Nd}}$ compositions of world carbonatites (<200Ma) compared with oceanic basalts (from Hofmann, 1997) basalts, i.e. they contain no evidence of contributions from enriched sub-continental lithospheric mantle (SCLM), despite experimental evidence suggesting derivation at lithospheric mantle depths. Most carbonatites plot within a zone linking the oceanic island data used to define the HIMU and EM-I mantle reservoirs (Hofmann, 1997) with a smaller group (complexes from India, South America and Australia) overlapping the EM-II oceanic islands (see Fig.3). Close correspondence between carbonatite and OIB $\varepsilon_{\mathrm{Sr}}-\varepsilon_{\mathrm{Nd}}$ data was used to argue for a plume origin for carbonatites (Nelson et al., 1988).

Definitive evidence for a deep mantle source for carbonatites is provided by new data from the Karooaged (185Ma) Dorowa and Shawa carbonatites and associated nephelinitic rocks of the Buhera district of SE Zimbabwe. These nephelinites are the time equivalents of the nephelinitic to picritic volcanism which initiated the Karoo magmatism in the Nuanetsi and north Lebombo (NNL) regions. Extensive studies of the NNL volcanics indicate that their isotopic characteristics are the result of contamination of sub-lithospheric material with SCLM-sourced isotopicallyanomalous partial melts. The Buhera nephelinites have $\varepsilon_{\mathrm{Sr}}-\varepsilon_{\mathrm{Nd}}$ values which extend the NNL signatures to more negative $\varepsilon_{N d}$ values. By implication, then, the Buhera nephelinites are composed of a greater proportion of the SCLM component than the NNL picrites and nephelinites. Dolomitic carbonatites from the Shawa complex have $\varepsilon_{\mathrm{Sr}}-\varepsilon_{\mathrm{Nd}}$ of around $(+4,+1)$ and so must be derived from a mantle region which had not experienced the ancient enrichment reflected in the NNL and Buhera nephelinitic rocks. The isotopic signature of the dolomitic sample from Dorowa is intermediate

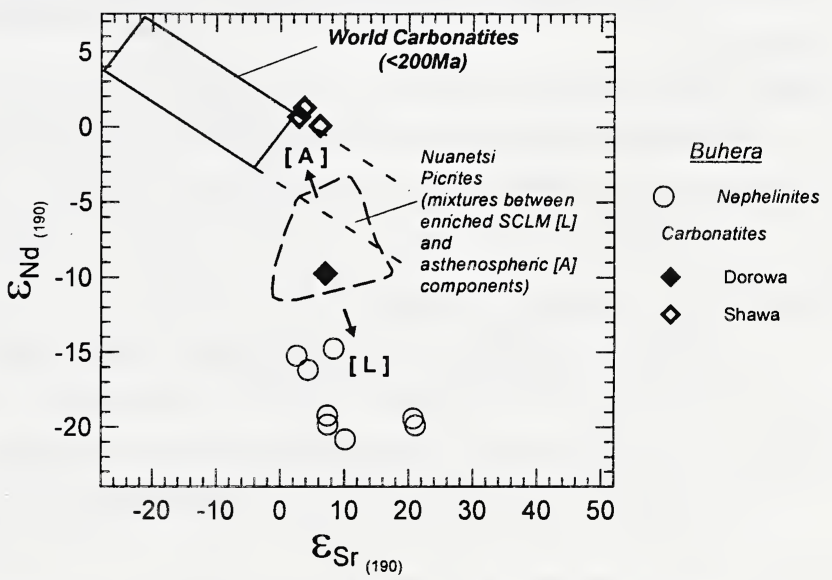

Figure 4: $\varepsilon_{\mathrm{Sr}}-\varepsilon_{\mathrm{Nd}}$ data for Buhera carbonatites and associated nephelinites. Data and interpretation of Nuanetsi picrites is from Ellam and Cox (1992). between these extremes presumably reflecting incorporation of some SCLM component by the carbonatite during ascent. By implication, then, the source of these carbonatites must lie below that of the enriched SCLM, in the convecting mantle. Furthermore, the Dorowa carbonatite must have existed as a discrete carbonate melt at the time it came into contact with the enriched SCLM material from which the nephelinitic magmas were derived. 


\section{Relationships between carbonatites, kimberlites, orangeites and lamproites}

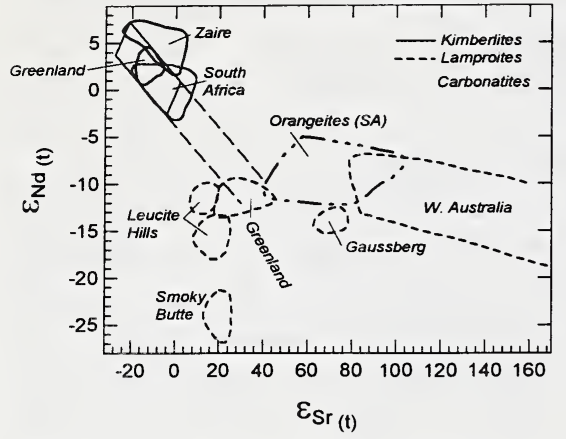

Figure 5: $\varepsilon_{\mathrm{Sr}}-\varepsilon_{\mathrm{Nd}}$ data for carbonatites (shaded box and array - from Fig. 3), kimberlites, orangeites and lamproites

A characteristic shared between carbonatites, kimberlites and lamproites is an extreme enrichment in incompatible elements, enrichment levels that generally require pre-enrichment of the mantle source regions. Available $\varepsilon_{\mathrm{Sr}^{-}} \varepsilon_{\mathrm{Nd}}$ data for kimberlites and carbonatites are closely comparable (Fig.5) suggesting derivation from similar source regions. The depleted $\varepsilon_{\mathrm{Sr}}-\varepsilon_{\mathrm{Nd}}$ signatures of these rocks indicate that any preenrichment must have happened close to the time of magma genesis. Experimental data reviewed earlier indicate that carbonatites separate from the mantle at depths of $75-100 \mathrm{~km}$ whereas kimberlites must separate at substantially greater depths than this. Data such as that from the Buhera carbonatites suggest that much of the trace element budget in carbonatites ( $\mathrm{Sr}$ and LREE at least) is ultimately derived from sub-lithospheric sources. Lamproites and orangeites are isotopically distinct from carbonatites and kimberlites and indicate derivation from lithospheric mantle segments which had long-lived enrichments in LREE and $\mathrm{Rb} / \mathrm{Sr}$. Unlike kimberlites and carbonatites, enrichment of the lamproite/orangeite source must have pre-dated magmatism by $>1 \mathrm{Ga}$.

\section{Conclusions}

Isotopic and experimental data indicate that carbonatites are derived from primitive carbonate melts produced by melting of carbonated mantle peridotite. Limited variability in $\varepsilon_{\mathrm{Sr}}-\varepsilon_{\mathrm{Nd}}$ values in young carbonatites emplaced through widely dispersed and compositionally diverse lithospheres suggest that these characteristics are inherited from sub-lithospheric mantle.

\section{References}

Ellam, R.M., Carlson, R.W. and Shirey, S.B. 1992. Evidence from Re-Os isotopes for plumelithosphere mixing in Karoo flood basalt genesis. Nature, 359, 718-721.

Hofmann, A.W. 1997. Mantle geochemistry: the message from oceanic volcanism. Nature, 385, 219-229.

Ionov, D.A., Dupuy, C., O'Reilly, S.Y., Koplova, M.G. and Genshaft, Y.S. 1993. Carbonated peridotite xenoliths from Spitsbergen: implications for trace element signature of mantle carbonate metasomatism. Earth Planet. Sci. Lett., 119, 283-297.

Nelson, D.R., Chivas, A.R., Chappell, B.W. and McCulloch, M.T. 1988. Geochemical and isotopic systematics in carbonatites and implications for the evolution of ocean-island sources. Geochim. Cosmochim. Acta, 52, 1-17.

Rudnick, R.L., Mcdonough, W.F. and Chappell, B.W. 1993. Carbonatite metasomatism in the northern Tanzanian mantle - petrographic and geochemical characteristics, Earth Planet. Sci. Lett., 114, 463-475.

Sweeney, R.J. 1994. Carbonatite melt compositions in the earth's mantle. Earth Planet. Sci. Lett., 128, 259-270.

Wallace, M.E. and Green, D.H. 1988. An experimental determination of primary carbonatite magma composition. Nature, 335, 343-346. 